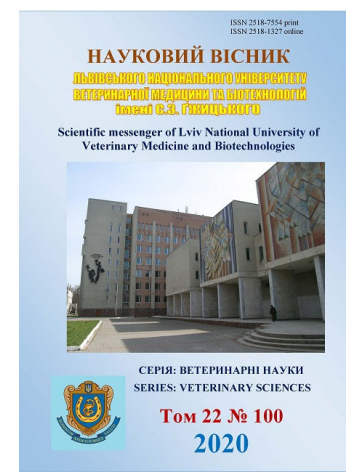

\author{
Науковий вісник Дьвівського національного університету \\ ветеринарної медицини та біотехнологій імені С.3. Гжицького. \\ Серія: Ветеринарні науки \\ Scientific Messenger of Lviv National University \\ of Veterinary Medicine and Biotechnologies. \\ Series: Veterinary sciences
}

UDC 547.497.6

\title{
Physiological properties and characteristic reactions of hydroxyurea
}

\author{
O. G. Demchuk, M. R. Hrytsyna, L. O. Kobryn, M. B. Kalytovska, B. V. Gutyj \\ Stepan Gzhytskyi National University of Veterinary Medicine and Biotechnologies Lviv, Ukraine
}

Article info

Received 15.10.2020 Received in revised form 16.11.2020 Accepted 17.11.2020

Stepan Gzhytskyi National University of Veterinary Medicine and Biotechnologies Lviv, Pekarska Str., 50, Lviv, 79010, Ukraine. Tel.: +38-097-255-17-98 E-mail: hrytsynamr@gmail.com
Demchuk, O. G., Hrytsyna, M. R., Kobryn, L. O., Kalytovska, M. B., \& Gutyj, B. V. (2020). Physiological properties and characteristic reactions of hydroxyurea. Scientific Messenger of Lviv National University of Veterinary Medicine and Biotechnologies. Series: Veterinary sciences, 22(100), 94-102. doi: 10.32718/nvlvet10017

As it was mentioned in the previous paper, we observed the mechanism of action the interesting drug, first synthesized back in 1869 for the first time, called Hydroxyurea. A century later, phase I and II trials began to test its safety in humans with solid tumors. It was first approved by the FDA in 1967 for the treatment of neoplastic diseases and is presently approved for the treatment of melanoma, resistant chronic myelocytic leukemia (CML), and recurrent, metastatic testicular and ovarian cancer. Sickle cell disease is a genetic disorder that decreases life expectancy by 25 to 30 years. Individuals are diagnosed with sickle cell disease if they have one of several genotypes that result in at least half of their hemoglobin being hemoglobin $S(H b S)$. Sickle cell anemia refers specifically to the condition associated with homozygosity for the Hb S mutation (Hb SS). Several other hemoglobin mutations, when occurring with an $\mathrm{Hb} S$ mutation, cause a similar but often milder disease than sickle cell anemia. In addition to reduced life expectancy, patients with sickle cell disease experience chronic pain and reduced quality of life. Painful crises, also known as vaso-occlusive crises, are the most common reason for emergency department use and hospitalization, and acute chest syndrome is the most common cause of death. Prior to the approval of hydroxyurea for use in sickle cell disease, patients with this condition were treated only with supportive therapies. These measures included penicillin in children to prevent pneumococcal disease, routine immunizations, and hydration and narcotic therapy to treat painful events. Red blood cell transfusions increase the blood's oxygen carrying capacity and decrease the concentration of cells with abnormal hemoglobin, but chronic transfusion therapy predictably leads to iron overload and alloimmunization. Therapies such as hydroxyurea that raise fetal hemoglobin $(H b F, \alpha 2 \gamma 2)$ levels are promising because they effectively lower the concentration of $H b S$ within a cell, resulting in less polymerization of the abnormal hemoglobin.Hydroxyurea's efficacy in sickle cell disease is generally attributed to its ability to raise the levels of Hb F in the blood; however, the mechanisms by which it does so are unclear. Early studies suggested that hydroxyurea is cytotoxic to the more rapidly dividing late erythroid precursors, resulting in the recruitment of early erythroid precursors with an increased capacity to produce $\mathrm{HbF}$.

Key words: hydroxyurea, hydroxycarbamide, colour reactions, metal complexes, quality control.

\section{Вивчення терапевтичної дії та кольорові реакції гідроксисечовини}

\author{
О. Г. Демчук, М. Р. Грицина, Л. О. Кобрин, М. Б. Калитовська, Б. В. Гутий
}

Львівський національний університет ветеринарної медицини та біотехнологій імені С. 3. Гжицького, м. Львів, Україна

Як згадувалося в попередній роботі, нами розглянули механізм дії иікавого препарату, вперше синтезованого ще в 1869 рочі, під назвою Гідроксисечовина. Через століття випробування I та II фаз почали перевіряти його безпеку у людей із солідними пухлинами. Вперше він був затверджений FDA в 1967 рочі для лікування пухлинних захворювань $і$ в даний час схвалений для лікування меланоми, стійкого хронічного мієлоцитарного лейкозу (ХМЛ) та рецидивуючого, метастатичного раку яєчок та яєчників. Серповидно-клітинна хвороба - че генетичний розлад, який зменшує тривалість життя на 25-30 років. У осіб діагностується серпо- 
видноклітинна хвороба, якщо вони мають один із кількох генотипів, в результаті яких принаймні половина їх гемоглобіну становить гемоглобін $S(H b S)$. Серповидноклітинна анемія конкретно відноситься до стану, пов 'язаного з гомозиготністю мутаиії Нb $S$ (Hb SS). Кілька інших мутачій гемоглобіну, коли виникають із мутацією Нb S, викликають подібне, але часто більи легке захворювання, ніж серповидноклітинна анемія. Окрім зменшення тривалості життя, пацієнти із серповидно-клітинною хворобою відчувають хронічний біль та зниження якості життя. Хворобливі кризи, також відомі як вазо-оклюзійні кризи, є найпоширенішою причиною використання відділення невідкладної допомоги та госпіталізації, а гострий синдром грудної клітки - найпоширеніша причина смерті. До затвердження гідроксисечовини для використання при серповидно-клітинній хворобі пачієнти з ицим захворюванням лікувались лише за допомогою допоміжних методів лікування. Ці заходи включали пеніцилін у дітей для профілактики пневмококової хвороби, планові імунізації, гідратацію та наркотичну терапію для лікування хворобливих явищ. Переливання еритрочитів збільшує пропускну здатність крові до кисню та зменшує концентрацію клітин з патологічним гемоглобіном, але хронічна трансфузійна терапія передбачає перевантаження залізом та алоімунізацію. Такі терапї, як гідроксисечовина, ццо підвищує рівень фетального гемоглобіну (Hb F, $\alpha 2 \gamma 2)$, є перспективними, оскільки вони ефективно знижують кониентрацію Нb $S$ в клітині, щзо призводить до меншої полімеризації аномального гемоглобіну. здатність підвищувати рівень Нb $F$ у крові; проте механізми, за допомогою яких він ие робить, неясні. У зв'язку з тим, щуо гідроксичечовина набирає все більшого поширення в клініuуі, а тепер затверджений в Україні є препарат під назвою “НU”, необхідно опрацювати вже існуючі характерні реакції і розробити нові методологї для перевірки якості застосовуваного препарату, як вихідної субстанції для виготовлення вітчизняного лікарського засобу.

Ключові слова: гідроксисечовина, гідроксикарбамід, кольорові реакиї, комплекси металів, контроль якості.

\section{Ветуп}

У попередній статті ми детально розглянули механізм дії HU (з англ. Hydroxyurea далі HU) на клітинному рівні. Використання високих концентрацій або тривале лікування низькими дозами $\mathrm{HU}$ може призвести до загибелі клітин. Причиною цитотоксичного ефекту препарату може виступати окислювальний стрес або пошкодження синтезу DNA, спричинене заблокованими реплікаційними вилками (Singh \& Xu, 2016).

Детальне вивчення фізіологічних властивостей оксиміду привело до висновку, що препарат може також застосовуватись у боротьбі зі злоякісними пухлинами, як інгібітор рибонуклеотидредуктази. У звязку з чим і почались його широкі клінічні дослідження. Клінічні дослідження препарату $\mathrm{HU}$ вперше проведено у 1963 р. на 143 хворих з різними злоякісними новоутвореннями, причому, при ін'єкційному введенні препарат $\epsilon$ менш токсичний, ніж при оральному прийомі. Оптимальною дозою для людини, яка легко переноситься і не викликає побічних явищ, є 1520 мг/кг маси (Thurman et al., 1963; Tanzer et al., 1966).

При клінічних дослідженнях, HU вводили 20 пацієнтам із хронічним мієлолейкозом. При цьому кількість лейкоцитів знизилася до норми у всіх пацієнтів, зменшилася анемія, спленомегалія зменшилася або зникла, відкоригувався тромбоцитоз і покращився стан кісткового мозку. $\mathrm{HU}$ не запобігала розвитку гострої фази хронічного мієлолейкозу, гемолізу або мієлофіброзу. HU така ж ефективна, як і бусульфан, і може застосовуватися як первинна терапія хронічного мієлолейкозу (Kennedy, 1972).

В лікувальній практиці $\mathrm{HU}$ використовують при лікуванні серповидно-клітинної анемії, поліцитемії, ессенціальної тромбоцитемії, псоріазу, гострого мієлоїдного лейкозу, менінгіоми, меланоми та раку яєчників. Детальне вивчення фізіологічних властивостей оксиміду привело до висновку, що препарат може також застосовуватись у боротьбі зі злоякісними пухлинами, як інгібітор рибонуклеотидредуктази. У зв'язку з чим і почались його широкі клінічні дослідження (Singh \& Xu, 2016).
Клінічний досвід застосування HU для пацієнтів із серповидно-клітинними захворюваннями (СКЗ) накопичується протягом останніх 25 років. Більшість досліджень свідчать про те, що HU є добре переносимою, безпечною та ефективною для більшості пацієнтів із СКЗ. Так, у пацієнтів, що приймали $\mathrm{HU}$ рівень гемоглобіну був більшим, ніж при лікуванні плацебо. Середня кількість кризів була на $44 \%$ меншою, ніж у групі плацебо. У дорослих, спостерігалося відносне підвищення рівня фетального гемоглобіну з $4 \%$ до $20 \%$ та відносне зниження рівня кризи з $68 \%$ до $84 \%$ (Steinberg et al., 1997; Lanzkron et al., 2008).

Американське управління з санітарного нагляду за якістю харчових продуктів та медикаментів схвалило використання $\mathrm{HU}$ для дорослих пацієнтів з серповидно-клітинною анемією, однак ії використання у дітей залишається до кінця не вивченим. В результаті досліджень було встановлено, що просте класичне лікування серповидноклітинної анемії у дітей - переливання крові та хелація залишаються кращим способом, ніж використання HU. Це клінічне випробування було зареєстровано на Clinical Trials.gov NCT00122980 (Ware \& Helms, 2012). Незважаючи на велику кількість доказів щодо ефективності та безпеки $\mathrm{HU}$, в даний час вона призначається досить рідко пацієнтам із СКЗ. Автори вважають, що необхідно подолати бар'єри щодо її використання (Russell, 2009; Ware \& Helms, 2012).

Часто HU використовують в комплексному лікуванні разом з радіотерапією чи іншими препаратами, 3 якими вона проявляє синергічну дію. Так, вона проявляє синергію з радіаційними або алкілуючими агентами та гальмує відновлення ДНК, пошкодженої хімікатами або опроміненням. Також спостерігається синергія між $\mathrm{HU}$ i хіміотерапевтичними засобами цитарабін та етопозид. HU робить клітини чутливими до блеоміцину, який також має цитотоксичну активність. Вона пригнічує вільний радикал тирозилу, який більше не стабілізує сусідній центр заліза, роблячи його більш сприйнятливим до хелатних властивостей блеоміцину, який потім виробляе активний кисень.

Для лікування хронічного мієлолейкозу (ХМЛ) була досліджена комбінація препаратів Іматинібу (IM) та HU (HU). Комбінація IM / HU була більш 
ефективною у селективному інгібуванні клітин ХМЛ in vitro, але не перевершувала IM у клінічних дослідженнях (Lange et al., 2020).

Дослідження останніх років показали, що непереносимість HU розвивається у 20-30 \% пацієнтів 3 поліцитемією і пов'язана з підвищеним ризиком тромбоутворення та зниженням виживання. Нещодавно була запропонована молекулярна класифікація мієлопроліферативних новоутворень на основі секвенування геному. Ця геномна класифікація розподіляє пацієнтів 3 цією хворобою на вісім молекулярних груп і може бути корисною для виявлення пацієнтів стійких до гідросечовини, що дасть можливість правильно підібрати препарати і покращить якість ї лікування. Удосконалення профілактичних заходів щодо тромбозу є суттєвим у пацієнтів з гомозиготною мутацією ЈАK2, які лікуються HU. I навпаки, пацієнти, що належать до гетерозиготної категорії мутацій JAK2, можуть отримати вигоду від довготривалого лікування $\mathrm{HU}$, яке супроводжується низьким рівнем резистентності, тромбозу та прогресування захворювання (Alvarez-Larrán et al., 2020).

Більшість гематологів схильні уникати інтенсивного лікування, надаючи перевагу підтримуючій терапії. Лікарі Тайланду встановили, що метрономічна хіміотерапія може продовжити життя важко хворих на гострий мієлоїдний лейкоз пацієнтів, особливо в перші 12 місяців після встановлення діагнозу, не збільшуючи побічних явищ, пов'язаних 3 лікуванням HU. Вони висловили гіпотезу, що метрономна хіміотерапія може бути альтернативним методом лікування важко хворих пацієнтів на гострий мієлоїдний лейкоз (Pongudom et al., 2020).

Хемочутливість до НU ракових клітин легенів людини вивчали in vitro. При концентрації HU $1 \mathrm{mM}$ в сироватці крові вона здійснювали 99 \% інгібування росту клітин. При внутрішньовенному введенні дозу збільшували від 24 г за 24 год до 48 г за 48 год. Найбільша концентрація проявляла мієлосупресією. Пероральне введення HU не призвело до стійких рівнів, порівнянних $з$ тими, що досягались при безперервній інфузії. Встановлено, що $\mathrm{HU}$ можна вводити в дозах до 48 г за 48 год протягом трьох тижнів з незначною токсичністю для тканин і кісткового мозку, а досягнуті рівні in vivo в крові необхідні для ефективного інгібування онкоклітин, як у відповідній моделі in vitro (Veale et al., 1988).

HU в експерименті пригнічувала ріст аденокарциноми молочної залози Н2712, особливо коли її вводили на початковій стадії росту пухлини. Ця сполука була ефективною при щоденній, періодичній або одноразовій ін'єкції та при введенні безпосередньо в пухлину (Lerner et al., 1966). В експерименті було доказано, що HU інгібує ріст культивованих клітин менінгіоми у мишей, викликаючи апоптоз. HU призначалася як допоміжне хіміотерапевтичне лікування у пацієнтів 3 рецидивуючими та нерезультативними менінгіомами. Тривале лікування HU може призвести до повної ремісії пухлин у пацієнтів із менінгіомою (Schrell et al., 1997).
Звичайно, варто звернути увагу і на вивчення побічних ефектів HU, при довготривалому прийомі препарату може виникнути ризик канцерогенезу або лейкемії. Аналізи цитогенетики та молекулярної генетики пацієнта 3 ускладненнями після вживання препарату продемонстрували складний мутаційний профіль із делецією 5q, трисомією 8 та делецією Р53 (делеція 17p13.1) хромосом. Дослідження послідовності генів Р53 виявили безліч соматичних мутацій. Вищезазначені дані вказують на те, що у пацієнта міг розвинутися гострий мієлоїдний лейкоз із змінами, пов'язаними 3 мієлодисплазією (AML-MRC), як прямий результат впливу HU (Regan et al., 2019). У молодого пацієнта із серповидноклітинною хворобою, який майже 5 років лікувався HU. розвинулося рідкісне захворювання гостра еритроїдна лейкемія (Yadav et al., 2020).

Для визначення HU розроблений спектрофотометричний метод. Методологія передбачає відновлення $\mathrm{HU}$ стандартного перманганату калію $\left(\mathrm{KMnO}_{4}\right)$, приготовленого в 1н. середовищі сірчаної кислоти. $\mathrm{KMnO}_{4}$ має $\lambda_{\max }$ при 525 і 545 нм. Зменшення поглинання для даного розчину $\mathrm{KMnO}_{4}$ додаванням $\mathrm{HU}$ порівнюють із розчином без гідросечовини, що має однакову концентрацію $\mathrm{KMnO} 4$. Встановлено, що

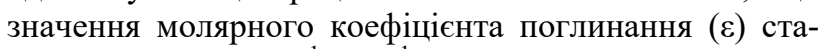
новить 957 моль $^{-1} \cdot{ }^{-} \mathrm{cm}^{-1} 3$ точністю до $3,8 \%$. Коефіцієнт кореляції становив 0,9975. Встановлено, що лінійний динамічний діапазон цього методу становить від 10 до 80 ppm HU. Також вивчався вплив кислотності та температури на стабільність НU в азотнокислому середовищі. Також вивчали кислотну залежність від радіаційного впливу розчину HU та залежність дози стабільності розчину HU (Sivakumar et al., 2013).

Проведено хроматографічні дослідження як методи очистки та розділення суміші HU і іiі домішки незаміщеної сечовини на хроматографічних колонках нітрильного та амідного типу. При використанні нітрильної колонки Zorbax SB CN 150'4,6 мм (5 мкм) для поділу суміші $\mathrm{HU}$ та іiі домішки сечовини як рухому фазу використали суміші ацетонітрилу і води. Поділ аналізованих сполук в умовах рідинної хроматографії гідрофільних взаємодій можливо при вмісті ацетонітрилу в рухомій фазі більше 90 \%. При хроматографуванні на нітрильній колонці Zorbax SB CN спостерігалася зміна черговості елюювання $\mathrm{HU}$ і сечовини порівняно 3 елююванням на аміноколонці Zorbax $\mathrm{NH}_{2}$ (Osipov et al., 2016).

Проведено хроматографічні дослідження як методи очистки та розділення суміші HU і їі домішки незаміщеної сечовини на хроматографічній колонці Поділ аналізованих сполук на амідних колонках XBridge Amide 150'4,6 мм (3,5 мкм) як рухомі фази застосовували ті ж самі суміші ацетонітрилу і води в умовах рідинної хроматографії гідрофільних взаємодій можливо при вмісті ацетонітрилу в рухомій фазі більше 93 \%. При хроматографуванні на амідній колонці XBridge Amide спостерігалася зміна черговості елюювання HU і сечовини порівнянј з елюювання на діольних і нітрильних хроматографічних колонках. 
Хроматографія сумішей сечовини і НU на даних колонках може бути застосована для підтвердження придатності хроматографічної системи при аналізі сечовини методом високоефективної рідинної хроматографії (Osipov et al., 2017).

Дослідження (Souza et al., 2020) мало на меті розробити якісні методи ідентифікації НU та перевірки їі чистоти. Препарат HU входить до Бразильського національного списку основних лікарських засобів, i, незважаючи на його клінічну важливість не представлений монографією у Бразильській фармакопеї. На додаток до органолептичних тестів, була використана ІЧ- та УФ-спектроскопія, а також методики тонкошарової хроматографії ТШХ. ІЧ- та УФ-спектри показали сумісність та максимальне поглинання при 213 нм. Для ТШХ випробовували різні розчинники чистого чи градієнта полярності із задовільними результатами для рухомої фази, що містить ацетон та етилацетат (99 : 1). В цьому останньому випадку заміна рухомої фази 3 тієї, що описана у фармакопеях, призвела до зменшення кількості хімічних відходів, мінімізуючи при цьому ризики для здоров'я оператора, відповідно до основної концепції зеленої аналітичної хімії.

\section{Матеріал і методи досліджень}

Дослідження, проведені в ЦНДЛ та на кафедрі фармакології Львівського медичного інституту довели, що HU на відміну від інших часто застосовуваних в клініці імунодепресантів, інгібує утворення антитіл, як до введення антигенів, так і після їх введення (Romanyuk et al., 1986), а також проявляють іншу важливу фізіологічну дію HU, а саме - здатність коагулювати кров, причому - 3 деякими перевагами навіть перед вікасолом (Vladzimirska et al., 1984). Поєднання характеристичних функціональних груп від гідроксиламіну $\mathrm{H}_{2} \mathrm{NOH}$ i карбамінової кислоти $\mathrm{H}_{2} \mathrm{NCOOH}$, тобто N-карбаміноїлгідроксиламіну у своїй хімічній структурі, забезпечує характерні кольорові реакції гідроксисечовини (Faygl, 1962).<smiles>NC(=O)NO</smiles>

Наявність відповідних характерних груп, а також дослідження спектральних методів (УФ-спектри поглинання), які доводять достовірність молекулярної структури діючої речовини і їі реакційну здатність. Крім цього, порівняння УФ-спектрів поглинання $\mathrm{HU}$ i незаміщеного карбаміду дає можливість більш детально дослідити електронну структуру цієї сполуки (Sverdlova, 1973).

HU має сильні відновні властивості, а саме вона відновлює реактив Фелінга 3 утворенням $\mathrm{Cu}_{2} \mathrm{O}$ - осаду цеглового кольору, а з аміачним розчином $\mathrm{AgNO}_{3}$ дає реакцію срібного дзеркала (Dresler et al., 1869).

При дослідженні інфрачервоних спектрів HU, iii ізомеру порівняно зі спектром незаміщеного карбаміду доводить, що спектри всіх трьох речовин мають смуги в ділянці $3300-3400 \mathrm{~cm}^{-1}$, які відносяться до валентних коливань $\mathrm{NH}$ i - смугу в ділянці 1650 $1700 \mathrm{~cm}^{-1}$, що належить до $\mathrm{C}=\mathrm{O}$. Проте, в спектрі $\mathrm{HU}$ спостерігається інтенсивна смуга поглинання при $2800 \mathrm{~cm}^{-1}$, якої немає в спектрах незаміщеного карбаміду та ізооксикарбаміду (ізомер HU).

Для дослідження кольорових реакцій $\mathrm{HU}$ використали такі реагенти: 0,1 \% розчини солей $\mathrm{Fe}^{3+}, \mathrm{Cu}^{2+}$, $\mathrm{Co}^{2+}, \mathrm{Ni}^{2+}, \mathrm{Ag}^{+}, \mathrm{Pt}^{4+}$, реактиви: Зоненштейна, Бушарда, Несслера, Драгендорфа, а також розчини: пдиметиламінобензальдегіду, фосфорновольфрамової кислоти i пентаціаноаміноферату натрію (Vladzimirskaya et al., 1974).

Приготування вихідних розчинів

Розчини солей $\mathrm{Fe}^{3+}, \mathrm{Cu}^{2+}, \mathrm{Co}^{2+}, \mathrm{Ni}^{2+}, \mathrm{Ag}^{+}$i $\mathrm{Pt}^{4+}$ готували з розрахунку концентрації 1 мг /1 мл катіону (0,1 \% в перерахунку на відповідний катіон) згідно всіх аналітичних вимог. Використовують хімічно чисті кристалічні солі $\mathrm{FeCl}_{3}, \mathrm{CuSO}_{4}, \mathrm{Co}\left(\mathrm{NO}_{3}\right)_{2}, \mathrm{NiCl}_{2}$, $\mathrm{AgNO}_{3}, \mathrm{PtCl}_{4}$, зважують відповідну кількість на аналітичних терезах 3 точністю 0,1 мг і розчиняють дистильованою водою в мірній колбі на 100 мл.

Отримання реактиву Зоненштейна

10,0 г амонію молібдату розчиняють в 100 мл дистильованої води, додають 100 г $26 \%$ розчин $\mathrm{HNO}_{3}$ ( $\rho 1,163)$, суміш нагрівають 2 год на киплячому водяному нагрівнику, охолоджують і додають $25 \%$ розчин $\mathrm{H}_{3} \mathrm{PO}_{4}$ до ще випадання осаду фосфорної солі молібдату амонію. Осад відфільтровують, промивають і переносять в круглодонну колбу, кип'ятять з царською горілкою до розчинення. Залишок розчиняють в 100 мл $10 \% \mathrm{HNO}_{3}$ і відфільтровують.

Одержання пентаціаноаміноферату натрію

До 5,0 г розтертого в порошок натрію нітропрусиду додають 20 мл концентрованого розчину аміаку і суміш залишають на 24 год у холодильнику, потім відфільтрують. До фільтрату додають метанол доти, поки ще випадає осад, який відфільтровують і промивають метанолом. Висушують в вакуум-ексикаторі. 1,0 г отриманого пентаціаноаміноферату натрію розчиняють в 100 мл дистильованої води у колбі Ерленмейєра, яку через добу закривають притертим корком і залишають в темному місці.

Реактив Бушарда - розчин хлорплатинової і фосфорновольфрамової кислоти (в 1 мл - 3 мг $\mathrm{PtCl}_{4}$ ) випускається промисловістю у готовому вигляді.

\section{Результати та їх обговорення}

3 метою виконання якісних реакцій $\mathrm{HU}$ з описаними вище реагентами і дослідженням умов, при яких виникає зміна забарвлення реакційної суміші, приготували $0,01 \%$ та $0,1 \%$ водні розчини препарату.

До 1мл реактиву в пробірці додають 1 краплю 0,1 \% розчину HU і спостерігають утворення характерного забарвлення. Якщо від додавання 10 крапель $0,1 \%$ розчину HU не наступає жодних змін кольору розчину, то така реакція вважається негативною. У випадку негативної реакції реакційну суміш нагрівають до кипіння і спостерігають можливі зміни. В проведених експериментах ефект нагрівання реакційної суміші веде до підсилення інтенсивності забарв- 
лення і спостерігався лише в реакції з пентаціаноамінофератом натрію.

При негативних реакціях проводились також досліди зі зміною реакційного середовища, наприклад в аміачному розчині. 3 цією метою до 1 мл реактиву додавали 5 крапель концентрованого розчину аміаку, а потім краплями $0,1 \%$ розчин HU у воді. Так, в цих умовах $0,1 \%$ розчин $\mathrm{Co}\left(\mathrm{NO}_{3}\right)_{2}$ у воді в присутності $\mathrm{HU}$ від додавання 5 крапель розчину аміаку викликає жовто-зелене забарвлення реакційної суміші, однак, при наявності 4 крапель $0,1 \%$ розчину $\mathrm{HU}$ виникало рожеве забарвлення, а не жовто-зелене.
Для реакції утворення ефекту “срібного дзеркала" 1 мл $0,1 \%$ розчину $\mathrm{AgNO}_{3}$ необхідно нагріти на водяному нагрівнику 3 5-ма краплями концентрованого розчину аміаку в присутності 6 крапель $0,1 \%$ розчину HU.

У реакції з ферум (III) хлоридом $\mathrm{FeCl}_{3}$ фіолетове забарвлення виникає від додавання 1 краплі розчину HU. Тому до 1 мл $0,1 \%$ розчину $\mathrm{Fe}^{3+}$ додавали краплями, розведений у 10 разів розчин $\mathrm{HU}(0,01 \%)$, що свідчить про високу чутливість реакції та можливість iii використання для аналітичних цілей.

Результати досліджень представлені в таблиці 1.

\section{Таблиця 1}

Характерні реакції гідроксисечовини

\begin{tabular}{|c|c|c|c|c|c|}
\hline $\begin{array}{l}\text { № } \\
\Pi / \Pi\end{array}$ & Реактив & Реакція (ефект) & $\begin{array}{c}\text { Ефект } \\
\text { нагрівання }\end{array}$ & $\begin{array}{c}\text { Ефект додавання } \\
\text { аміаку при негативній } \\
\text { реакції }\end{array}$ & Примітка \\
\hline 1. & $0,1 \%$ p-H Fe3+ & $\begin{array}{l}\text { Блідо-фіолетове забарв- } \\
\text { лення при додаванні } 22 \\
\text { крапель } 0,01 \% \text { розчину HU }\end{array}$ & - & - & - \\
\hline 2. & $\begin{array}{l}\text { Реактив Зоненш- } \\
\text { тейна }\end{array}$ & $\begin{array}{l}\text { Посилення жовто-зеленого } \\
\text { забарвлення від } 2 \text { крапель } \\
0,1 \text { \% розчину гідроксиче- } \\
\text { човину }\end{array}$ & - & - & - \\
\hline 3. & $\begin{array}{l}1 \% \text { р-н пента- } \\
\text { ціаноаміноферату } \\
\text { натрію }\end{array}$ & $\begin{array}{l}\text { Червоно-коричневе забар- } \\
\text { влення від } 1 \text { краплі 0,1\% p- } \\
\text { ну гідроксичечовину }\end{array}$ & $\begin{array}{l}\text { Посилення } \\
\text { забарвлення }\end{array}$ & - & - \\
\hline 4. & $0,1 \%$ р-н Co $2+$ & - & - & $\begin{array}{l}\text { Рожеве забарвлення } \\
\text { від } 4 \text { крапель } 0,1 \% \text { р- } \\
\text { ну гідроксичечовини }\end{array}$ & $\begin{array}{l}\text { Реактив при додаванні } 5 \\
\text { крапель р-ну аміаку } \\
\text { утворює жовто-зелене } \\
\text { забарвлення }\end{array}$ \\
\hline 5. & $0,1 \%$ р-н $\mathrm{Cu} 2+$ & - & - & - & $\begin{array}{l}\text { Реактив від додавання } 5 \\
\text { крапель р-ну аміаку } \\
\text { утворює синє забарвлен- } \\
\text { ня (не виникає при від- } \\
\text { сутності гідроксичечо- } \\
\text { вини) }\end{array}$ \\
\hline 6. & $0,1 \%$ p-H Ni2+ & - & - & - & - \\
\hline 7. & $\begin{array}{l}\text { Р-н фосфорно- } \\
\text { вольфрамової к-ти } \\
\text { за ДФ-Х }\end{array}$ & - & - & - & - \\
\hline 8. & 0,1\%p-н AgNO3 & $\begin{array}{l}\text { Реакція срібного дзеркала } \\
\text { від додавання } 6 \text { крапель } \\
0,1 \% \text { р-ну гідроксичечови- } \\
\text { ну }\end{array}$ & $\begin{array}{l}\text { Реакція } \\
\text { проходить } \\
\text { при нагрі- } \\
\text { ванні }\end{array}$ & 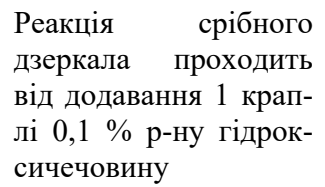 & - \\
\hline 9. & Реактив Бушарда & - & - & - & - \\
\hline 10. & $0,3 \%$ p-н Pt4+ & - & - & - & - \\
\hline 11. & Реактив Неслера & - & - & - & - \\
\hline 12. & Реактив Майєра & - & - & - & - \\
\hline
\end{tabular}

Поява забарвлення спостерігається з іонами $\mathrm{Fe}^{3+}$ в нейтральному середовищі і з іонами $\mathrm{Co}^{2+}-$ в аміачному розчині. Також кольорову реакцію дає з HU пентаціаноамінофератом натрію. В цей же час катіони $\mathrm{Pt}^{4+}$, $\mathrm{Cu}^{2+} \mathrm{i} \mathrm{Ni}^{2+}$, реактиви Зоненштейна і Бушарда, розчини п-диметиламінобензальдегіду і фосфорновольфрамової кислоти не давали видимих реакцій.

При змішуванні розчину $\mathrm{AgNO}_{3} 3$ розчином $\mathrm{HU}$ видима реакція не проходить. Не спостерігається також реакція при додавані аміаку. Однак, при нагріванні цих розчинів утворюється реакція “срібного дзеркала”, причому чутливість реакції в нейтральному розчині 0,27 мг, а в аміачному - 0,02 мг HU.

Оскільки HU здатна гідролізувати 3 утворенням аміаку, вуглекислого газу і гідроксиламіну (незаміщений карбамід гідролізує з утворенням аміаку і вуглекислого газу) за реакцією:

$$
\underset{\mathrm{O}}{\mathrm{H}_{2} \mathrm{~N}-\mathrm{C}-\mathrm{NHOH}}+\mathrm{H}_{2} \mathrm{O} \longrightarrow \mathrm{NH}_{3} \uparrow+\mathrm{CO}_{2} \uparrow+\mathrm{NH}_{2} \mathrm{OH}
$$


то реакцію з нітратом срібла в аміачному середовищі можна пояснити, як окисно-відновну реакцію (Cheng, 2017).

Враховуючи те, що $\mathrm{NH}^{+}$катіон міг бути індукований $3 \mathrm{NH} 2 \mathrm{OH} \cdot \mathrm{HCl}$ як м'який відновлюючий агент для відновлення іонів срібла. Відновлююча здатність

$$
[\mathrm{Ag}(\mathrm{NH} 3) 2]^{+}+2 \mathrm{NH}_{2} \mathrm{OH}
$$

Особливо характерні реакції спостерігаються при взаємодії $\mathrm{HU}$ з $\mathrm{FeCl}_{3}$ і з $\mathrm{Co}\left(\mathrm{NO}_{3}\right)_{2}$. В першому випадку виникає фіолетове забарвлення в нейтральному середовищі, причому HU можна виявити в кількості 20 мг в пробі. В другому випадку рожеве забарвлення виникає тільки в аміачному середовищі, при цьому реакція є значно менш чутливою, що дає можливість визначити HU в кількості 181,6 мг в пробі.

За багатьма хімічними реакціями (гідроліз і подібні реакції ) гідроксамові кислоти, як і гідразиди, схожі на аміди; своєрідно зв'язані з фрагментом N-OH. Гідроксамові кислоти проявляють більш сильніші кислотні властивості, ніж аміди, а також гідразиди; їх кислотність приблизно того ж порядку, що і фенолів. Цим і пояснюється здатність до утворення забарвлених комплексів 3 такими іонами як $\mathrm{Fe}^{3+}, \mathrm{Cu}^{2+}, \mathrm{Al}^{3+}$ та рядом інших; 3 врахування утворення бідентатних комлексів хелатної будови.

У реакціях НU з солями $\mathrm{Fe}^{3+}$ i $\mathrm{Co}^{2+}$ не має окисновідновного характеру, іiі слід розглядати як реакцію

$$
\mathrm{H}_{2} \mathrm{~N}-\underset{\mathrm{O}}{\mathrm{C}}-\mathrm{OC}_{2} \mathrm{H}_{5}+\mathrm{NH}_{2} \mathrm{OH}
$$

Можна припустити, що трьохвалентне залізо координую молекулу НU тривалентним, а гідроксичечовина - триосновною гідроксамовою кислотою, в зв'язку з чим іон заліза може зв'язувати три залишки
$\mathrm{NH}_{2}{ }^{+}$недостатня для відновлення $\mathrm{Ag}^{+}$до металевого срібла, отже, додаткова концентрація розчину аміаку та нагрівання реакційної суміші, призвела до утворення аміачного комплексу іону $\left[\mathrm{Ag}\left(\mathrm{NH}_{3}\right)_{2}\right]^{+}$, що $\epsilon$ більш реакційним у реакції відновлення. Ця реакція може бути виражена як:

$$
\mathrm{Ag} \downarrow+2 \mathrm{NH}_{4}^{+}+\mathrm{N}_{2}+2 \mathrm{H}_{2} \mathrm{O}
$$

комплексоутворення 3 відповідними таутомерними формами гідроксамових кислот:<smiles>[R]C(=O)NO</smiles>

HU в метанолових розчинах знаходиться у таутомерній рівновазі зі своїм ізомером (Vladzimirskaya et al., 1981): при розведенні розчинів зростає кількість гідроксамової таутомерної форми -

$$
\mathrm{H}_{2} \mathrm{~N}-\mathrm{C}-\mathrm{C}-\mathrm{NHOH}
$$

і зменшується кількість імідної таутомерної форми

$$
\begin{gathered}
\mathrm{H}_{2} \mathrm{~N}-\mathrm{C}=\mathrm{C}-\mathrm{OH} \\
\mathrm{OH}
\end{gathered}
$$

HU можна розглядати, як похідне гідроксамових кислот, а саме - карбамінової кислоти.

Згідно методу добування гідроксичечовини, внаслідок реакції уретану (етилового естеру карбамінової кислоти) 3 гідроксиламіном в лужному середовищі утворюється гідроксамові кислоти за схемою:

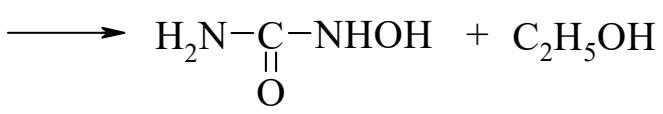

HU. Однак, ми досліджували реакції з високим надлишком $\mathrm{FeCl}_{3}$ і тому, по аналогії реакції $\mathrm{FeCl}_{3}$ з фенолом (яка є добре дослідженою) можна передбачити, що отримана сполука має таку структуру:<smiles></smiles>

Оскільки, у водному розчині іони кобальту (II) icнують у вигляді комплексів гексааквакобальтату (II) $\left[\mathrm{Co}\left(\mathrm{H}_{2} \mathrm{O}\right)_{6}\right]^{2+}$. Вони $є$ дуже стійкими і мають рожеве забарвлення. Додавання аміачного розчину до цих

комплексів, викликає появу синього осаду гідроксиду кобальту (II), який розчиняється при надлишкому додаванні аміаку, утворюючи гексаамінкобальтату (II), який має блідо-жовте забарвлення.

$$
\left[\mathrm{Co}\left(\mathrm{H}_{2} \mathrm{O}\right)_{6}\right]^{2+}(\text { водн. })+6 \mathrm{NH}_{3}(\text { водн. }) \rightarrow\left[\mathrm{Co}\left(\mathrm{NH}_{3}\right)_{6}\right]^{2+}(\text { водн. })+6 \mathrm{H}_{2} \mathrm{O}(\text { p. })
$$

Найбільш достовірно, що кобальтова сіль HU буде мати подібну структуру комплексу бідентатної природи, як у випадку з залізом.

Слід також зауважити, що атоми заліза і кобальту легко координують атоми азоту, і в зв'язку з цим в хімічній літературі описано немало різних заміщених аміакатів цих двох елементів (Frimantl, 1991).

Аналогічне комплексоутворення нами виявлено і у випадку реакції HU 3 аміачним розчином сульфату міді (1 мл $0,1 \%$ водного розчину $\mathrm{Cu}^{2+}$ утворює 3 5-ма 
краплями концентрованого розчину аміаку синє забарвлення). Однак, якщо до розчину $\mathrm{Cu}^{2+}$ попередньо додати 10 крапель $0,1 \%$ розчину $\mathrm{HU}$, то реакційна суміш залишається без змін. На основі цього експе-<smiles>NC(=O)NO</smiles>

Реакція $\mathrm{HU} 3 \mathrm{AgNO}_{3} є$ окисно-відновною і відбувається 3 утворенням “срібного дзеркала". Таким чином, HU можна виявити 3 допомогою $\mathrm{AgNO}_{3}$ (в нейтральному чи аміачному середовищі) за відсутності класів органічних сполук, що реагують 3 аміачним розчином срібла. 3 солями $\mathrm{Fe}^{3+}, \mathrm{Co}^{2+}$ (в аміачному середовищі), пентаціанофератом натрію (в нейтральному середовищі) та 3 реактивом Зоненштейна (в нейтральному середовищі).

\section{Висновки}

Практичне значення таких досліджень полягає в тому, що на основі встановлення чутливості окремих кольорових реакцій $є$ можливість розробити методики ідентифікації і кількісного визначення HU в технологічних формах і в біологічних розчинах.

Таким чином, HU можна виявити 3 допомогою $\mathrm{AgNO}_{3}$ (в нейтральному чи аміачному середовищі) за відсутності класів органічних сполук, що реагують 3 аміачним розчином срібла. 3 солями $\mathrm{Fe}^{3+}, \mathrm{Co}^{2+}$ (в аміачному середовищі), пентаціанофератом натрію (в нейтральному середовищі) та 3 реактивом Зоненштейна (в нейтральному середовищі). HU вступає в реакцію взаємодії з $\mathrm{Co}\left(\mathrm{NO}_{3}\right)_{2}$ в аміачному середовищі $\mathrm{i} \mathrm{FeCl}_{3}$ з утворенням комплексних сполук, що мають рожеве та відповідно фіолетове забарвлення.

На УФ-спектрах поглинання концентрованих метанолових розчинів (біля $1 \%$ д) для гідроксисечовину $є$ характерний максимум поглинання при 224 нм, який при розведенні цих розчинів зміщується гіпсохромно до 204 нм (для 15,63 мг/\% розчину).

На противагу гідроксисечовину незаміщений карбамід в метаноловому розчині характерний лише одним низькоінтенсивним максимумом поглинання при 202 нм, який відповідає р-л спряженню в амідному хромофорі.

\section{References}

Adams, R. L., \& Lindsay, J. G. (1967). Hydroxyurea reversal of inhibition and use as a cell-synchronizing agent. J Biol Chem, 242(6), 1314-1317. URL: https://pubmed.ncbi.nlm.nih.gov/6023572.

Alvarez-Larrán, A., Díaz-González, A., Such, E. et al. (2010). Genomic characterization of patients with polycythemia vera developing resistance to hydroxyurea. Leukemia, 2020. doi: 10.1038/s41375020-0849-2.

Boyd, A. S., \& Neldner, K. H. (1991). Hydroxyurea therapy. Journal of the American Academy of Dermatology, 25(3), 518-524. рименту можна припустити, що НU утворює 3 катіонами міді комплексну сполуку слідуючої структури:<smiles></smiles>

Charache, S., Terrin, M. L., \& Moore, R. D. (1995). Effect of hydroxyurea on the frequency of painful crises in sickle cell anemia. Investigators of the Multicenter Study of Hydroxyurea in Sickle Cell Anemia. N Engl J Med, 332(20), 1317-1322. doi: 10.1056/NEJM199505183322001.

Cheng, Z.-P., Chu, X.-Z., Wu, X.-Q., Xu, J.-M., Zhong, H., \& Yin, J.-Z. (2017). Controlled synthesis of silver nanoplates and nanoparticles by reducing silver nitrate with hydroxylamine hydrochloride. Rare Metals, 36(10), 799-805. doi: 10.1007/s12598-017-0949-y.

Davies, B. W., Kohanski, M. A., Simmons, L. A., Winkler, J. A., Collins, J. J., \& Walker, G. C. (2009). Hydroxyurea induces hydroxyl radical-mediated cell death in Escherichia coli. Molecular cell, 36(5), 845860. doi: 10.1016/j.molcel.2009.11.024.

Donehower, R. C. (1992). An overview of the clinical experience with hydroxyurea. Seminars in Oncology, 19(9), 11-19. URL: https://pubmed.ncbi.nlm.nih.gov/ 1641651.

Dresler, W. F. C., \& Stein, R. (1869). Ueber den Hydroxylharnstoff; Annalen Der Chemie Und Pharmacie, 150(2), 242-252. doi: 10.1002/jlac.18691500212.

Faygl, F. (1962). Kapelnyiy analiz organicheskih veschestv. M. (in Russian).

Frimantl, M. (1991). Himiya v deystvii, tom 2, izd. "Mir", M. (in Russian).

Gibbs, M. A., \& Sorensen, S. J. (2000). Hydroxyurea in the treatment of HIV-1. Annals of Pharmacotherapy, 34(1), 89-93. doi: 10.1345/aph.19004.

Gwilt, P. R., \& Tracewell, W. G. (1998). Pharmacokinetics and Pharmacodynamics of Hydroxyurea. Clin Pharmacokinet, 34, 347-358. doi: 10.2165/00003088-199834050-00002.

Kennedy, B. J. (1972). Hydroxyurea therapy in chronic myelogenous leukemia. Cancer, 29(4), 1052-1056. doi: 10.1002/1097-0142(197204)29:1<1052::AIDCNCR2820290454>3.0.CO;2-7.

King, S. B. (2004). Nitric oxide production from hydroxyurea. Free Radical Biology and Medicine, 37(6), 737-744. doi: 10.1016/j.freeradbiomed.2004.02.073.

Lange, T., Niederwieser, C., Gil, A., Krahl, R., von Grünhagen, U., Al-Ali, H. K., \& Junghanss, C. (2020). No advantage of Imatinib in combination with hydroxyurea over Imatinib monotherapy: a study of the East German Study Group (OSHO) and the German CML study group. Leukemia \& Lymphoma, 1-10. doi: 10.1080/10428194.2020.1786556.

Lanzkron, S., Strouse, J. J., Wilson, R., Beach, M. C., Haywood, C., Park, H., Witkop, C., Eric, E. B., \& Segal, J. B. (2008). Systematic Review: Hydroxyurea 
for the Treatment of Adults with Sickle Cell Disease. Ann. Intern. Med, 148(12), 939-955. URL: https:/www.ncbi.nlm.nih.gov/pmc/articles/PMC3256 736.

Lerner, L. J., Bianchi, A., Yiacas, E., \& Borman, A. (1966). Effects of hydroxyurea and related compounds on the blood and marrow of experimental animals. Cancer research, 26(11 Part 1), 2292-2296. URL: https://cancerres.aacrjournals.org/content/26/11 Part $1 / 2292$.

Margaretten, W., Morgan, C., Rosenkranz, H. S., \& Rose, H. M. (1966). Effect of Hydroxyurea on Virus Development I. Electron Microscopic Study of the Effect on the Development of Bacteriophage T4. Journal of bacteriology, 91(2), 823-833. URL: https://www.ncbi.nlm.nih.gov/pmc/articles/PMC3149 36.

Nii, S., Rosenkranz, H. S., Morgan, C., \& Rose, H. M. (1968). Electron microscopy of herpes simplex virus III. Effect of hydroxyurea. Journal of virology, 2(10), 1163-1171. URL: https://www.ncbi.nlm.nih.gov/pmc/ articles/PMC375449.

Osipov, A. S., Nechaeva, E. B., \& Truhacheva, L. A (2016). Chromatographic column with nitrile sorbent used in the analysis of hydroxycarbamide by hydrophilic interaction liquid chromatography. The Bulletin of the Scientific Centre for Expert Evaluation of Medicinal Products, 3, 58-61 (in Russian).

Osipov, A. S., Popova, O. A., Larionova, S. G., \& Timoshina, E. Yu, (2017). Hydrophylic interaction chromatography used for separation of hydroxycarbamide and urea. The Bulletin of the Scientific Centre for Expert Evaluation of Medicinal Products, 7(2), 81-84 (in Russian).

Pongudom, S., Phinyo, P., Chinthammitr, Y., Charoenprasert, K., Kasyanan, H., Wongyai, K., ... \& Surawong, A. (2020). Efficacy and Safety of Metronomic Chemotherapy Versus Palliative Hydroxyurea in Unfit Acute Myeloid Leukemia Patients: A Multicenter, Open-Label Randomized Controlled Trial. Asian. Pacific. Journal of Cancer Prevention, 21(1), 147-155. doi: 10.31557/APJCP.2020.21.1.147.

Regan, S., Yang, X., Finnberg, N. K., El-Deiry, W. S., \& $\mathrm{Pu}$, J. J. (2019). Occurrence of acute myeloid leukemia in hydroxyurea-treated sickle cell disease patient. Cancer biology \& therapy, 20(11), 1389-1397. doi: 10.1080/15384047.2019.1647055

Romanyuk, Yu. P., Demchuk, O. G., \& Melnik, A. N. (1986). Sravnitelnoe izuchenie immunodepressivnogo deystviya imohlena, osimochevinyi i imurana $\mathrm{v}$ eksperimente. Sb. "Optimizatsiya lekarstvennogo obespecheniya i puti povyisheniya effektivnosti farmatsevticheskoy nauki", Harkov (in Russian).

Rosenkranz, H. S., Rose, H. M., Morgan, C., \& Hsu, K. C. (1966). The effect of hydroxyurea on virus development: II. Vaccinia virus. Virology, 28(4), 510-519. doi: 10.1016/0042-6822(66)90235-2

Russell, E. (2009). Ware, Banu Aygun; Advances in the use of hydroxyurea. Hematology Am Soc Hematol Educ Program 2009, 1, 62-69. doi: 10.1182/asheducation-2009.1.62.
Rutschmann, O. T., Opravil, M., Iten, A., Malinverni, R., Vernazza, P. L., Bucher, H. C., \& Perrin, L. H. (1998). A placebo-controlled trial of didanosine plus stavudine, with and without hydroxyurea, for HIV infection. Aids, 12(8), 71-77. doi: 10.1097/00002030199808000-00003.

Souza, S. S., dos Santosa, I. G., da Silvaa, C. V., \& Laignier Cazedey, E. C. (2020). Qualitative Analysis of Hydroxyurea. Drug Anal. Res., 4(1), 18-21. doi: $10.22456 / 2527-2616.100682$.

Schrell, U. M., Rittig, M. G., Anders, M., Kiesewetter, F., Marschalek, R., Koch, U. H., \& Fahlbusch, R. (1997). Hydroxyurea for treatment of unresectable and recurrent meningiomas. I. Inhibition of primary human meningioma cells in culture and in meningioma transplants by induction of the apoptotic pathway. Journal of neurosurgery, 86(5), 845-852. doi: 10.3171/jns.1997.86.5.0840.

Sinclair, W. K. (1965). Hydroxyurea: differential lethal effects on cultured mammalian cells during the cell cycle. Science, 150(3704), 1729-1731. doi: $10.1126 /$ science.150.3704.1729.

Singh, A., \& Xu, Y. J. (2016). The Cell Killing Mechanisms of Hydroxyurea. Genes (Basel), 7(11), 99. doi: 10.3390/genes7110099.

Sivakumar, P., Meenakshi, S., Govindan, R. V., \& Subba, Rao (2013). Spectrophotometric determination of hydroxyurea and stability in nitric acid medium. International Journal of Nuclear Energy Science and Engineering, 3(2), 27-31. URL: https://issuu.com/sep2011-now/docs/3 88872b3a1d3fbf.

Steinberg, M. H., Lu, Z. H., Barton, F. B., Terrin, M. L., Charache, S., \& Dover, G. J. (1997). Fetal hemoglobin in sickle cell anemia: determinants of response to hydroxyurea. Blood Adv., Am. J. Hematol., 89(3), 1078 1088. URL: https://pubmed.ncbi.nlm.nih.gov/9028341.

Sverdlova, O. V. (1973). Elektronnyie spektryi v organicheskoy himii. L.: Himiya (in Russian).

Tanzer, J., Jacquillat, C., Weil, M., Levy, D., Najean, Y., Boiron, M., \& Bernard, J. (1966). Effects of hydroxyurea in chronic myeloid leukemia. Preliminary study. La Presse medicale, 74(56), 2929-2930.

Thurman, W. G., Bloedow, C., Howe, C. D., Levin, W. C., Davis, P., Lane, M., Sullivan, M. P., \& Griffith, K. M. (1963). A phase I study of hydroxyurea. Cancer Chemother. Rep., 29, 103-107. URL: https://pubmed.ncbi.nlm.nih.gov/13981319.

Veale, D., Cantwell, B. M. J., Kerr, N., Upfold, A., \& Harris, A. L. (1988). Phase 1 study of high-dose hydroxyurea in lung cancer. Cancer Chemother Pharmacol, 21(1), 53-56. doi: 10.1007/BF00262739.

Vladzimirska, O. V., Soronovich, I. I., Rudiy, R. V., Hveschuk, L. G. (1984). Vivchennya novogo protileykoznogo zasobu "oksisechovina" ta produktIv yiyi peretvorennya. Farmatsevtichniy zhurnal, 34-37 (in Ukrainian).

Vladzimirskaya, O. V., \& Demchuk, O. G. (1974). Harakternyie reaktsii oksimochevinyi. Sb. "Vsesoyuznoe soveschanie po analiticheskomu kontrolyu proizvodstva lekarstvennyih i farmatsevticheskih preparatov", Perm, 1974, 113 (in Russian). 
Vladzimirskaya, O. V., Turkevich, N. M., \& Melnik, V. F. (1981). Tautomeriya protivoleykoznogo preparata oksimochevinyi. Farmatsiya, 2, 17-19 (in Russian).

Ware, R. E., \& Helms, R. W. (2012). Stroke with transfusions changing to hydroxyurea (SWiTCH). Blood Adv., Am. J. Hematol., 119(17), 3925-3932. doi: 10.1182/blood-2011-11-392340.

Wilson, J. G., Scott, W. J., Ritter, E. J., \& Fradkin, R. (1975). Comparative distribution and embryotoxicity of hydroxyurea in pregnant rats and rhesus monkeys. Teratology, 11(2), 169-178. doi: 10.1002/ tera.1420110205.

Yadav, D. K., Paul, T., Alhamar, M., Inamdar, K., \& Guo, Y. (2020) Pure erythroid leukemia in a sickle cell patient treated with hydroxyurea. Case Rep. Oncol., 13, 857-862. doi: 10.1159/000508361. 